\title{
Examination of fiscal expenditures on education and research as human capital investments
}

\author{
Judit T. Kiss ${ }^{1, *}$ \\ ${ }^{1}$ University of Debrecen, Department of Engineering Management and Enterprise, 4028 Debrecen, Hungary
}

\begin{abstract}
The economic role of knowledge, education and research as investments in individuals' human capital has become a real focus of attention among researchers and policy makers in Europe over the last few decades. Individuals' high level skills and the versatile knowledge acquired in a formal or informal educational context have become extremely important factors in evolving knowledge-based economies. In this article we primarily analyze fiscal expenditures on education, and on research and development among OECD countries, and examine the change over time of state expenditures on education.
\end{abstract}

\section{Introduction}

Research and development, investments in knowledge have an increasingly important role in enabling adaptability to economic change, and in contributing to economic growth at both a national and a regional level.

The economic and social impact of expenditures on health, R\&D (Research and Development), education and training as investments into individuals' human capital have been examined over several decades G. S. Becker [1], A. Case, D. Lubotsky, and C. Paxson [2], M. Grossman [3], W. Groot, and H. Maassen van den Brink [4], S. M. Lynch [5], J. Mincer [6], [7], G. Psacharopoulos, and H. A. Patrinos [8], [9], T. W. Shultz [10], [11]. Many researchers have analyzed the positive impact of human capital investments on economic growth, and the positive externalities of expenditures on health, education and training for the economy and society at large G. S Becker, K. M. Murphy, and R. Tamura [12], R. E. Lucas [13], R. R. Nelson, and E. S. Phelps [14], T. W. Shultz [15], S. Rebelo [16], P. M. Romer [17], [18].

The European Commission developed a strategy for smart, sustainable and inclusive growth in 2010. The proposed objectives include, among others, support to increase the proportion of the population aged 30-34 who have completed tertiary education (from $31 \%$ to at least $40 \%$ ), to achieve a target of investing 3\% of GDP (Gross Domestic Product) in R\&D, and to reduce the proportion of early school leavers to $10 \%$ [19].

In what follows, we examine the change over time in public expenditures on education and research and development. We try to analyze whether or not the state spent more on education between 2005 and 2013, and research and development between 2006 and 2012, in OECD countries.

\section{The development of public expenditures on education}

Usually, the level of public expenditure on education exceeds that of private educational expenditures. This relationship is one of the reasons why private rates of return to education are greater than fiscal rates of return and social rates of return to education. Investment in human capital can be partially characterized by public expenditure on education as a percentage of total public expenditure.

The OECD and EU22 averages for public educational expenditures as a percentage of total public expenditures were $11.2 \%$ and $9.9 \%$ in 2013 . The lowest value for the indicator examined occurred in Hungary $(6.8 \%)$ in 2013 [Fig.1].

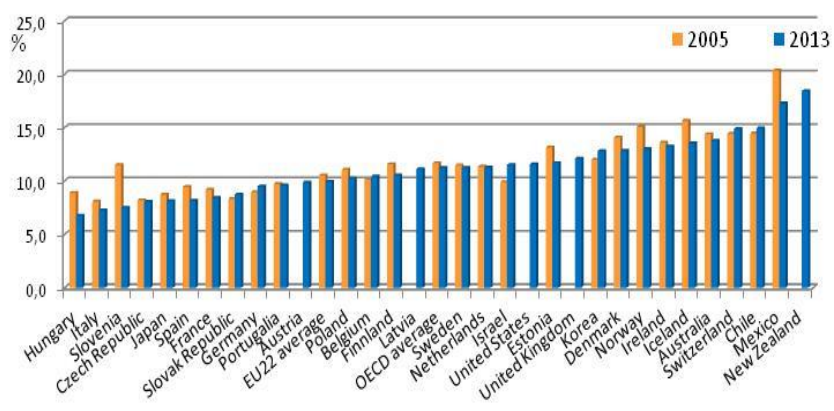

Fig. 1. Public expenditures on education as a percentage of total public expenditures, 2005 and 2013 [20]

In international comparative terms, we can see that between 2005 and 2013 the level of this indicator decreased in most countries. The largest decrease occurred in Slovenia, Mexico, Hungary, and Iceland,

\footnotetext{
Corresponding author: tkiss@eng.unideb.hu
} 
falling by $4 ; 3.1 ; 2.1$ and 2.1 percentage points, respectively [Figs. 1, 2].

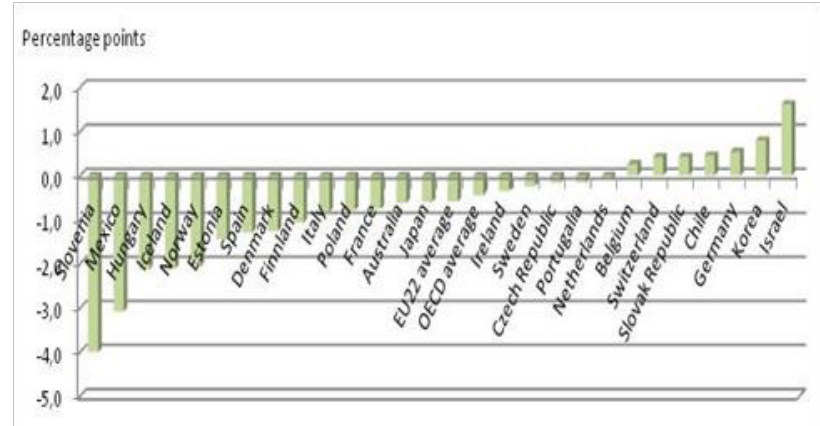

Fig. 2. The change in public expenditures on education as a percentage of total public expenditures, between 2005 and 2013 [20]

It should be noted that public spending on education as a percentage of total public expenditures may decrease if the State provides fewer resources for education compared to the other items of public expenditure, or the amount of total public resources decreases. If the level of State revenues decreases, the State should decrease resources allocated for different areas. This increase in total public expenditures as a percentage of GDP could be observed in most OECD countries for which data were available between 2005 and 2013 [Fig. 3]. However, the indicator decreased moderately (by 0.2 percentage points) in Hungary in the investigated period [Fig. 3]. The greatest increase could be found in Greece (16.73 percentage points); however, interpreting this change can be misleading without a knowledge of GDP data. The decrease in GDP was greater than the increase in the total public expenditure to GDP ratio in Greece during the examined period. This means that total public expenditures decreased in Greece.

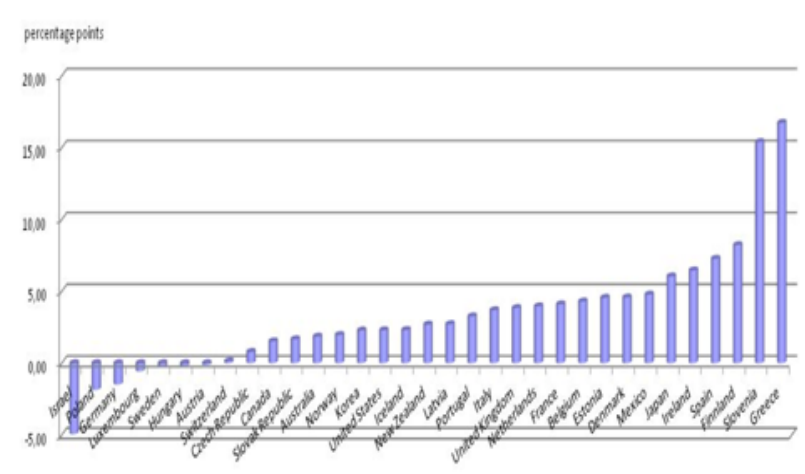

Fig. 3. The change in total public expenditure as a percentage of GDP in OECD countries, between 2005 and 2013 [20]

Despite the increase in the total public spending to GDP ratio, total public expenditures decreased, similarly to Greece, due to the larger decrease in GDP in several countries, including the Mediterranean member states (in Italy, Portugal, Spain) and Ireland.

It is also notable that while the most significant decrease in total public expenditures between in 2005 and 2013 occurred in Israel (by 4.94 percentage points)
[Fig. 3], public expenditures on education increased to the greatest extent in Israel (by 1.6 percentage points) [Fig. 2] during the same period. In the case of Israel, it can be established that the state paid particular attention to education as investment in human capital; however, this statement does not necessarily hold for Hungary. Despite the moderate increase in total public expenditures, public spending on education decreased in Hungary between 2005 and 2013. Public expenditures on education between 2005 and 2013 decreased in most countries covered by the investigation.

Expenditures on education, training and research and development can be appreciably different for countries with different levels of development. In the following section, we examine public expenditures on education as a proportion of GDP.

\section{Public expenditures on education as a percentage of GDP, between 2005 and 2013}

The level of expenditures on education as an investment in human capital can be affected by the economic development of a country. In this section, we examine how public expenditures on education differ across countries with different levels of economic development.

In 2013, public education expenditures as a percentage of GDP ranged from $3.3 \%$ to $7.3 \%$ in countries involved in the investigation. The OECD and EU22 averages in 2013 were $4.8 \%$ and $4.7 \%$, respectively [Fig.4].

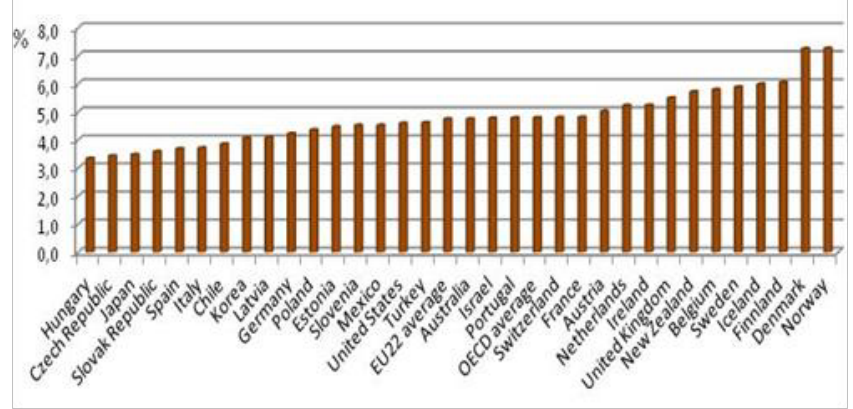

Fig. 4. Public expenditures on education as a percentage of GDP, in 2013 [20]

The highest level of public educational expenditures in relation to GDP occurred in Norway (7.3\%), Denmark $(7.2 \%)$, Finland $(6 \%)$, and Iceland $(6 \%)$. However we found the smallest value of this indicator for Hungary $(3.3 \%)$, where it was 1.5 percentage points lower than the OECD average (and 1.2 percentage points lower than the EU22 average).

Between 2005 and 2013 public education spending as a percentage of GDP increased in most countries for which analyzed data were available. The value of the indicator decreased in 8 (out of 26) countries between 2005 and 2013 [Table 1]. The largest decreases in the indicator occurred in Norway and Hungary (by 1.3 and 1.1 percentage points, respectively) [Table 1]. 
Table 1. The change in public expenditures on education as a percentage of GDP, between 2005 and 2013 [20]

\begin{tabular}{|c|c|c|c|}
\hline Country & $\begin{array}{c}\text { Change } \\
\text { (2005-2013) } \\
\text { (percentage } \\
\text { points) }\end{array}$ & Country & $\begin{array}{c}\text { Change } \\
\mathbf{( 2 0 0 5 - 2 0 1 3 )} \\
\text { (percentage } \\
\text { points) }\end{array}$ \\
\hline Norway & -1.3 & $\begin{array}{c}\text { OECD } \\
\text { average }\end{array}$ & 0.1 \\
\hline Hungary & -1.1 & Germany & 0.1 \\
\hline Slovenia & -0.6 & Israel & 0.2 \\
\hline Poland & -0.6 & Portugal & 0.2 \\
\hline Iceland & -0.5 & Mexico & 0.2 \\
\hline Sweden & -0.2 & Australia & 0.3 \\
\hline Switzerland & -0.1 & Japan & 0.3 \\
\hline Italy & -0.1 & Slovak & 0.3 \\
\hline France & 0.0 & Finland & 0.3 \\
\hline $\begin{array}{c}\text { Czech } \\
\text { Republic }\end{array}$ & 0.0 & Netherland & 0.4 \\
\hline Estonia & 0.0 & Korea & 0.5 \\
\hline Denmark & 0.0 & Belgium & 0.6 \\
\hline Spain & 0.1 & Chile & 0.6 \\
\hline $\begin{array}{c}\text { EU22 } \\
\text { average }\end{array}$ & 0.1 & Ireland & 0.7 \\
\hline
\end{tabular}

On the basis of the two indicators examined, most countries did not take any visible initiatives to respond to the challenges of the knowledge economy.

We continue our study by examining public expenditures on research and development. Given the absence of reliable data for the member states of the OECD for the period 2005 and 2013, the analysis is restricted to the period between 2006 and 2012.

\section{Public expenditures on research and development as a percentage of GDP, between 2006 and 2012}

In an economy, the public sector generally spends less on research and development compared to other macroeconomic sectors. Public expenditures on research and development in proportion to GDP in 2012 were the highest in Sweden (1.99\%), Finland (1.99\%), Denmark (1.91\%) and Germany $(0.96 \%)$ [Fig. 5]. The lowest values for this indicator occurred in Romania $(0.3 \%)$, Hungary $(0.43 \%)$, and Greece $(0.45 \%)$. The EU28 and OECD averages in 2012 were $0.74 \%$ and 0.71 , respectively [Fig. 5].

As we can see in Fig. 6, between 2006 and 2012 public expenditures on research and development as a percentage of GDP increased in all countries, with the exception of four.

Estonia, Korea, and Portugal where it increased by 0.35 , $0.3,0.26 ; 0.25$ percentage points, respectively [Fig. $5 ; 6$ ]. It can be observed that there was a positive movement in relation to research and development; however, there is room for improvement in Romania, Hungary and Greece. Between 2006 and 2012, public expenditures on research and development as a percentage of GDP decreased in Israel, Hungary, Canada and the United Kingdom by $0.14,0.07,0.04$ and 0.02 percentage points, respectively. The largest increase can be found in the Czech Republic, It should be noted that the decrease in the indicator examined occurred from a higher level in Israel, Canada and the United Kingdom. However, in Hungary the ratio of expenditure on research and development to GDP
$(0.5 \%)$ was significantly lower than the EU28 (0.65\%) and OECD $(0.64 \%)$ averages in 2006 . It cannot be stated that there was a positive change in relation to public spending on research and development in Hungary.

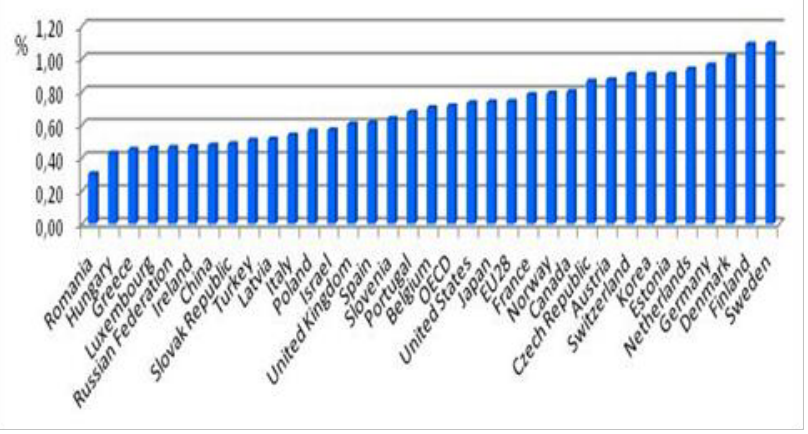

Fig. 5. Public expenditures on research and development

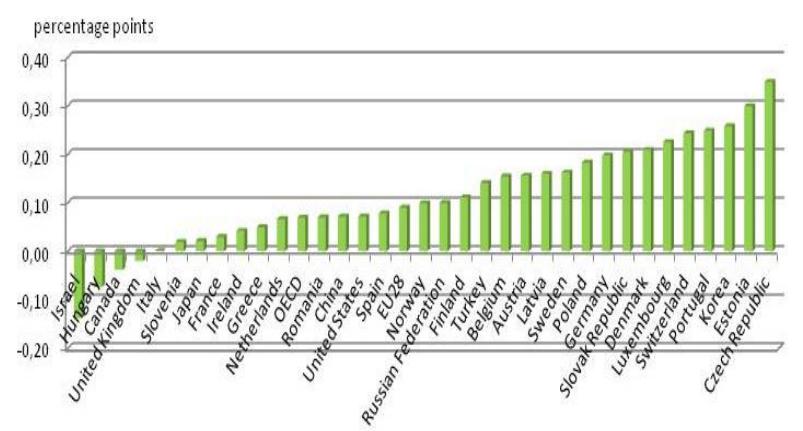

as a percentage of total GDP, in 2012 [21]

Fig. 6. Change in public expenditures on research and development as a percentage of total GDP, in 2012 [21]

\section{Conclusion}

In this study, we sought to examine the reactions of the public sector to the changing economic environment among OECD countries between 2005 and 2013, a task which requires increasing and versatile knowledge. Among other aspects, we analyzed public expenditures on education as a percentage of total public expenditures, and the change over time in the level of public expenditures on education as a percentage of GDP.

Between 2005 and 2013, public expenditures on education as a percentage of total public expenditures decreased in most OECD countries for which data were available. The indicator decreased to the greatest extent in Slovenia, Mexico, Hungary, and Iceland, falling by 4, $3.1,2.1$ and 2.1 percentage points, respectively. The decrease in the indicator examined in Hungary is noteworthy because in 2013 the lowest value of all was also recorded in Hungary.

The decreases in public expenditure on education in the period examined occurred against a background of rising total public expenditure. This indicates that the State provided fewer resources for education compared to the other areas of public expenditure in several countries among the OECD member states. 
We analyzed the development of public education expenditures as a percentage of GDP. This indicator ranged from $3.3 \%$ to $7.3 \%$ in 2013 . In the majority of countries for which analyzed data were available public expenditures on education were lower than the OECD average $(4.8 \%)$. Similarly to the ratio of public expenditure on education to total public expenditure, in 2013 the lowest value for the ratio of public spending on education to GDP could be found in Hungary (3.3\%), a value which was 1.5 percentage points lower than the OECD average. In Hungary, public spending on education was significantly below the EU22 and OECD averages, and the State spent less on education in terms of its economic development and compared to other countries during the period under investigation.

Beside the indicators discussed above, we analyzed public expenditure on research and development. In 2012 public expenditure on research and development as a percentage of GDP was above $1 \%$ in Sweden $(1.99 \%)$, Finland $(1.99 \%)$, and Denmark (1.91\%). In view of the change in this indicator, we can state that there is a positive movement in relation to public spending on research and development, because between 2006 and 2012 the indicator increased in most countries for which analyzed data were available. The largest increase occurred in the Czech Republic, Estonia, Korea, and Portugal, which recorded increases of $0.35,0.3,0.26$ and 0.25 percentage points, respectively. The public expenditure on research and development to GDP ratio was the lowest in Romania $(0.3 \%)$, Hungary $(0.43 \%)$ and Greece $(0.45 \%)$. However, we found positive changes in relation to this indicator in Romania and Greece, because there was a moderate increase in the ratio, of 0.07 and 0.05 percentage points, respectively.

\section{References}

1. G. S. Becker, The Journal of Political Economy. Vol. 70, Issue 5. Part 2: Investment in Human Beings. pp. 9-49. Oct, (1962)

2. A. Case, D. Lubotsky, and C. Paxson, The American Economic Review, Vol. 92, No. 5, pp. 1308-1334. (2002)

3. M. Grossman, In. N. E. Terleckyj (ed.), Household production and consumption, New York: National Bureau of Economic Research, pp. 147-224. (1976)

4. W. Groot, W. and H. Maassen van den Brink, Economics of Education Review, Vol. 26, pp. 186200. (2007)

5. S. M. Lynch, Journal of Health and Social Behaviour, Vol. 47, No. 4. pp. 324-338. (2006)
6. J. Mincer, The Journal of Political Economy. Vol. 66, Issue 4, pp. 281-302. (1958)

7. J. Mincer, Journal of Economic Literature, Vol. 8, No. 1, pp. 1-26. (1970)

8. G. Psacharopoulos, and H. A. Patrinos, World Bank Policy Research Working Paper 2881. (2002)

9. G. Psacharopoulos, and H. A. Patrinos, Education Economics, vol. 12(2), pages 111-134. (2004)

10. T. W. Schultz, The Journal of Political Economy.Vol. 68, No. 6, pp. 571-583. (1960)

11. T. W. Schultz American Economic Review. Vol. 51, No. 1, pp. 1-17. (1961)

12. G. S. Becker, K. M. Murphy, and R. Tamura, The Journal of Political Economy, Vol. 98, No. 5, Part 2: The Problem of Development: A Conference of the Institute for the Study of Free Enterprises Systems, S12-S37. (1990)

13. R. E. Lucas, Journal of Monetary Economics, Vol. 22, 3-42. (1988)

14. R. R. Nelson and Phelps, E. S, The American Economic Review, Vol. 56, No. 1/2. 69-75. (1966)

15. T. W. Schultz, Education and Economic Growth. In Social Forces Influencing American Education, ed. N. B. Henry, National Society for the Study of Education pp. 46-88. Chicago University of Chicago Press. (1961)

16. S. Rebelo, The Journal of Political Economy, Vol. 99, No. 3, (Jun., 1991), pp. 500-521. (1991)

17. P. M. RomerNBER Working Paper No. 3173. (1989)

18. P. M. Romer, The Journal of Political Economy. Vol. 98, No. 5, Part 2: The Problem of Development: A Conference of the Institute for the Study of Free Enterprise Systems. S71-S102. (1990)

19. European Commission, EUROPE 2020 A strategy for smart, sustainable and inclusive growth, http://ec.europa.eu/eu2020/pdf/COMPLET\%20EN $\% 20$ BARROSO $\% 20 \% 20 \% 20007 \% 20$ \%20Europe \%202020\%20-\%20EN\%20version.pdf. 2010. Accessed on 03.2016.

20. OECD, Education at a Glance, 2016. OECD Indicators. ISBN: 978-92-64-25979-9. (2016)

21. OECD, Main Science and Technology Indicators Database, June 2014, Science, technology and Industry Outlook, 2014, 978-92-64-25979-9. http://stats.oecd.org//Index.aspx?QueryId=57863. Accessed on 03.2017. 